\title{
A Review of Great Legal Traditions: Civil Law, Common Law, and Chinese Law in Historical and Operational Perspective
}

\author{
Leslie A. Burton ${ }^{*}$
}

\section{INTRODUCTION}

Three justices of the German Federal Constitutional Court, resplendent in red regalia, stand tall behind a high wooden bench and under an enormous carved eagle. A high ceiling emphasizes the splendor of the high court. The faces of Confucius, Constantine, and Blackstone, regal in their formal vestments, appear on the left. Superimposed text reads "Great Legal Traditions: Civil Law, Common Law, and Chinese Law in Historical and Operational Perspective." The startlingly vivid book cover commands visual attention, while its title promises an overview of the history of three legal systems along with their presentday procedures. But an impressive cover can disguise a tedious treatise. After all, one should not judge a book by its cover. But here, the text is as compelling as the cover. John W. Head's book fulfills the promise of its exterior.

Professor Head has chosen three legal systems - civil law, common law, and Chinese law_and has crafted a detailed and meticulously researched history of the roots of each system and their evolution over the ages. ${ }^{1}$ The book provides more than a mere history; it sets forth and embellishes upon the present-day workings of these three systems. ${ }^{2}$ The comprehensive treatment of these systems leaves little doubt that Great Legal Traditions will be of value to historians, sociologists, political scientists, law reformers, law students, and anyone interested in the interrelationship between law and history.

* Professor of Legal Writing and Director; LLM, U.S. Legal Studies Program, Golden Gate University School of Law, San Francisco, California.

1. John W. Head, Great Legal Traditions: Civil LaW, Common LaW, and Chinese LAW IN HISTORICAL AND OPERATIONAL PERSPECTIVE (2011).

2. Id. 


\section{SUMMARY}

An important perspective is missing from U.S. legal education. Law schools in the United States, unlike their European counterparts, fail to teach the roots of the law, or any legal history at all, except for a few scattered references to Olde England and Blackwell. This lapse is unfortunate because many young idealists enroll in law school with the desire to bring about change. They, as well as those uninterested in reform, would benefit from the lessons of history. After all, "the founders of modern comparative law were nearly all great legal historians." 3 True legal scholars as well as advocates for change should study legal history and the different approaches that different communities have taken in response to the same problems of the past.

Professor Head advocates for the study of law in an historical perspective. $^{4}$ In fact, he argues that a true understanding of the differences in legal systems requires a two-perspective approach. ${ }^{5}$ Professor Head thus takes the reader through the great legal traditions in "spatial" and "temporal" ways, examining their culture, history, and evolution. Yet Professor Head's book is not a "comparative law” text as such. Indeed, the author disparages that term, noting that there is no type of law called comparative law. He prefers the term "comparison of laws." 6

Noting that a theoretical approach to historical and cultural movements is not enough, Professor Head also examines contemporary practice. He recognizes that "[a] legal system has actual rules and institutions .... Hence it is necessary to look at the nuts and bolts of specific legal systems ... to see how each of the great legal traditions actually plays out in practice."7

The book is organized into seven chapters. Chapter One is an introduction to the concept of legal history, the contemporary operation of legal systems, and the value of the study of each. ${ }^{8}$ The next six chapters are arranged according to his two-perspective approach, dividing each of the three legal systems into both historical and

3. Konrad Zweigert \& Hein Kötz, An Introduction to COMParative LaW-The FRAMEWORK 8 (1977).

4. HEAD, supra note 1 , at $\mathrm{xix}-\mathrm{xx}$.

5. Id.

6. Id. at xix n.1.

7. Id. at 31 .

8. Id. at 3-40. 
operational perspectives. Chapter Two addresses civil law in the historical perspective, ${ }^{9}$ while Chapter Three addresses civil law in the operational perspective. ${ }^{10}$ Chapters Four and Five tackle the common law in the historical ${ }^{11}$ and operational ${ }^{12}$ perspectives, respectively. Lastly, Chinese legal tradition in the historical perspective is the focus of Chapter Six, ${ }^{13}$ while its operational perspective is discussed in Chapter Seven. ${ }^{14}$

\section{A. Civil Law}

Chapter Two covers the evolution of civil law in the western tradition, starting with class conflict in Ancient Rome, which led the way to attempts to codify Roman laws. ${ }^{15}$ It moves on through the effects of Christianity, the eclipse of the law in the "Dark Ages," the rediscovery of Justinian's Digest in the Renaissance, and the enactment of the French and German Civil codes. ${ }^{16}$ The sub-heading to one section of Chapter Two gives a good sense of the chapter's scope: "Republic and Empire, East and West, Polytheism and Christianity."17 The text documents every step along the road with footnotes, appendices, charts, and boxes of interesting side information. It is hard to imagine a more comprehensive coverage in a mere sixty-six pages.

Chapter Three is the first of the operational perspectives chapters. As he does in the other operational chapters, Professor Head discusses the sources of law and the players in the featured system. ${ }^{18}$ He explains the roles of judges, public prosecutors, government lawyers, advocates, and notaries, ${ }^{19}$ as well as the structures of the courts, the role of case law versus statutes, the licensing of lawyers, and the appointment of judges. ${ }^{20}$ And with each system's operational chapter, he concludes with a

\footnotetext{
9. Id. at $41-149$.

10. Id. at $151-327$.

11. Id. at 329-432.

12. Id. at 433-54.

13. Id. at 455-536.

14. Id. at $537-654$.

15. Id. at 45-60.

16. Id. at $60-110$.

17. Id. at 50 .

18. Id. at $157-74$.

19. Id. at 174-81.

20. Id. at 199-231.
} 
treatment of the criminal procedure as it functions in each of the systems. $^{21}$

The coverage of Chapter Three centers on Italy, a civil law country in which Professor Head spent time as a Fulbright scholar and of which he can speak from personal experience. ${ }^{22}$ As in the rest of the book, he has chosen entertaining and informative methods of dispensing information. He explains the Italian law school system through an interview with an Italian law student. ${ }^{23}$ The "Q and A" format makes for easy reading yet is thorough in its coverage. In the criminal procedure section, Professor Head uses contemporary real world cases to explain the workings of criminal procedure in a civil law system. ${ }^{24}$ He reprints a student's paper that outlines the procedural workings of the infamous murder case involving American exchange student Amanda Knox, who was accused of killing her British roommate, Meredith Kercher, in Perugia. ${ }^{25}$ The article was written for an American audience unfamiliar with the civil law criminal system and effectively clarifies the Italian court procedure. ${ }^{26}$ Finally, Professor Head includes a highly entertaining article that reimagines the O.J. Simpson trial through the eyes of a criminal lawyer in a civil law country. ${ }^{27}$ The article, written in the form of a screenplay by my colleague Myron Moskovitz, is a refreshing and non-judgmental comparison of the European and U.S. criminal law systems. Using modern stories-especially scandalous and controversial cases - is indeed an effective way to teach the law.

At the end of the chapter, Professor Head postulates that, historically, the shared Christianity of the European countries was a "glue" that held the civil law traditions together. ${ }^{28}$ Now that Europe has fewer Christians and the values of Christianity seem less important in the lives of many

21. Id. at $199-208$

22. Id. at 661 .

23. Id. at 188-99.

24. See, e.g., id. at 302-16 (discussing the Amanda Knox trial). Americans may be confused by the use of the term civil law in a criminal context. Unlike the common law, which labels all noncriminal cases as "civil" cases, the use of the word "civil" in this context denotes an entire system of law, which encompasses criminal law as a sub-part.

25. Christopher Griffith, The Foxy Knoxy Trial, in HEAD, supra note 1, at 302.

26. Id. at 302-16.

27. Myron Moskovitz, The O.J. Inquisition: A United States Encounter with Continental Criminal Justice, 28 VAND. J. TRANSNAT’L L. 1121 (1995), reprinted in HEAD, supra note 1, at 255. Professor Moskovitz was a member of the committee that hired me to teach at Golden Gate University in 1985. I owe him a debt of gratitude.

28. HEAD, supra note 1, at 236-37. 
Europeans, the civil law tradition may lose its adhesive power. ${ }^{29}$ Professor Head's provocative prediction rings true. As the composition of the world changes with globalization and increasing migration, populations will become more diverse. The effect that diversity has will be interesting to watch. One wonders whether diversity can bring strength, as it does in the evolution of species. ${ }^{30}$ In any event, an increasingly diverse society must learn the lessons of history as the law continues to evolve.

\section{B. Common Law}

Chapter Four covers the history and development of the common law tradition. It starts with the Celts and moves through the Norman Conquests, the early writ system, Blackstone's Commentaries, and the migration of the common law to England's colonies. ${ }^{31}$ It ends with the U.S. system. ${ }^{32}$ Chapter Four is another thorough and comprehensive treatment of many centuries of legal history compressed into fifty pages. Professor Head includes a sidebar explaining the Battle of Hastings and containing depictions of the battle taken from the Bayeux Tapestry. ${ }^{33}$

Professor Head uses his talent for simplifying concepts, explaining the clash between the principles of equity and the established principles of common law. ${ }^{34}$ He explains that the courts of equity arose in response to circumstances that were not appropriately covered by the common law. "It may also have seemed simpler, in fact, to evolve an entirely new legal system and judicial administration than to attempt to bring about

29. Id. at 237.

30. “Greater species diversity ensures natural sustainability for all life forms.” Anup Shah, Why Is Biodiversity Important? Who Cares?, GLOBAL IssuES, http://www.globalissues.org/article/170/ why-is-biodiversity-important-who-cares (last updated Apr. 6, 2011). "[T]he richer the diversity of life, the greater the opportunity for medical discoveries, economic development, and adaptive responses to such new challenges as climate change.” Id. (quoting U.N. Convention on Biological Diversity, opened for signature June 5, 1992, 1760 U.N.T.S. 143 (entered into force Dec. 29, 1993)) (internal quotation marks omitted).

31. HEAD, supra note 1 , at 329-82.

32. Id. at $378-82$.

33. Id. at 340-42 (citing William Fleming, ARTS \& IdEAS 115-18 (1974)). The Bayeux Tapestry depicts the events at the Battle of Hastings in 1066, in which William the Conqueror defeated King Harold of England to conquer England. Id. It is more than seventy meters in length, and while it is called a "tapestry," it is actually an embroidery that is made of woolen yarn on linen. Britain's Bayeux Tapestry, READING MusEum \& TOwN HALL, http://www.bayeuxtapestry.org.uk/ BayeuxInfo.htm (last visited Apr. 13, 2012).

34. HEAD, supra note 1, at 354-64. 
the reforms in the Common law that were so necessary at this time." ${ }^{35}$ He employs a sports metaphor to illustrate the point that the founding of the courts of equity allowed litigants to make an "end run" around the local courts if they could navigate through the writ system-and even then they probably would obtain only partial relief in a court of equity. ${ }^{36}$ "It was as if the football player ... [got] tackled by the opposing team's defensive line, but the referee provided certain protections from undue roughness, as by awarding additional yardage to the player if the defensive linesman tackled him too hard." ${ }^{\text {37 }}$ He finishes the common law history with commentary about the modern trend toward codification. $^{38}$

Chapter Five covers the operational aspects of the common law. Here, Professor Head departs from the organization of the earlier operational chapter-Chapter Three-by providing short, indented "Highlights" paragraphs at the start of each sub-heading. ${ }^{39}$ He is able to write Chapter Five in a more summary fashion because much of its information was included in Chapter Three in the course of contrasting the civil law traditions. He points out what should have been obvious to me but was not-the common law arose in the British Isles separately from the law of the European continent because of England's isolation from the rest of Europe. ${ }^{40}$ Although the European countries interacted with each other and exchanged the ideas that make up their civil law tradition, the English common law system stood alone-until it was exported to its colonies. ${ }^{41}$

Professor Head posits that, in the modern era, statutes and case law ${ }^{42}$

35. Id. at 356 (quoting RENÉ DAVID \& JoHN E.C. BRIERLEY, MAJOR LEGAL SySTEMS IN THE WORLD TODAY 325-26 (3d ed. 1985)) (internal quotation marks omitted).

36. Id. at 357 .

37. Id.

38. Id. at 364-82.

39. See, e.g., id. at $436,440,442$.

40. See id. at 435 (suggesting that the British Isles are outside the European "neighborhood").

41. Id. at 434-35.

42. The use of "caselaw" as if it were one word has grown increasingly popular. Black's Law Dictionary lists it in the one-word form as "caselaw," but it notes that it is "[a]lso written case law." BlACK's LAW DiCTIONARY 244 (9th ed. 2009). The example the dictionary gives, however, in which the defined term is used in a sentence, spells it as two words: "Case law in some form and to some extent is found wherever there is law." Id. (quoting Karl N. Llewellyn, Case Law, in 3 ENCYCLOPEDIA SOC. SCI. 249 (1930)). In fact, Professor Head reprints an article that uses the words "case law," yet he uses "caselaw" when inserting his own comments in brackets. HEAD, supra note 1 , at 441 . 
have "roughly equal weight" as sources of primary law. ${ }^{43}$ He quotes a treatise by René David and John E.C. Brierley when describing the superiority of case-driven common law over statute-based civil law: "[B]ecause it is founded on reason, the Common law has a non-national dimension.... [This] sets [it] above the arbitrariness of national politics and thus distinguishes [it]" from civil law systems. ${ }^{44}$ Indeed, argues Professor Head, the codes in Europe are "amenable for use by any particular form of government," in contrast to the common law, which "require[s] some restrictions on government." 45 His statements are disputable. Indeed, in the United States, the Constitution limits the types of statutes that Congress may pass, ${ }^{46}$ but aside from constitutional restrictions, Congress may enact or amend statutes at any time-surely just as easily as legislatures in civil law countries can. Further, it is hard to believe that only case law is based in reason. The choices made by an informed legislative body after examining both sides of an issue should be logical. Perhaps the author means that in today's partisan legislations, reason may not be relevant.

\section{Chinese Law}

In Chapter Six, Professor Head addresses Chinese law - the law that is least familiar to U.S. lawyers. Professor Head taught in Beijing in 1994 and can personally attest to some of the changes in China. ${ }^{47}$ Chinese history is ancient-longer than Europe's and certainly longer than the United States'-yet Professor Head rises to the challenge of summarizing it in eighty pages, ${ }^{48}$ after using sixty-six for the civil law system and fifty for the common law. He explains the historical concepts of Chinese law in his easy, conversational style. Chapter Six takes the reader from the law codes of dynastic China in the Second Century $\mathrm{BCE}^{49}$ through Communism ${ }^{50}$ and the Reform Mode of today. ${ }^{51}$ The most important movements in Chinese legal history have been the

\footnotetext{
43. HEAD, supra note 1 , at 436-42.

44. Id. at 440 (quoting DAVID \& BRIERLEY, supra note 35, at 396).

45. Id.

46. U.S. CONST. art. I, § 9.

47. HEAD, supra note 1 , at 661 .

48. Id. at $455-536$.

49. Id. at 459-505.

50. Id. at $513-20$.

51. Id. at 520-27.
} 
change from feudalism to imperialism, starting around 100 BCE, and "the growing urbanization and commercialization of Chinese life," which started in the Ninth Century CE. ${ }^{52}$ The enormity of this time span is enough to daunt most people, yet Professor Head tackles it without hesitation.

Professor Head uses examples to show that Chinese law is rooted in a debate about the innate nature of human beings. ${ }^{53}$ Confucius was a utopian who believed that government should be "placed in the hands of true gentlemen who were dedicated to the ritual and ceremony that ... had been the hallmark of a glorious past, and with law and punishment relegated to a very meager role."54 The Legalists took a dimmer view of humankind, believing that people would be more likely motivated by punishment than by moral example. ${ }^{55}$ This dispute has taken place around the world for centuries and continues today. In that way, the ancient Chinese arguments are quite contemporary.

Despite this ongoing dispute, Chinese law has maintained an amazing continuity. Through the centuries, Chinese law has set forth the same fundamental principles: harmony, ritual, stability, and moral virtue. $^{56}$ Professor Head notes that, unlike Westerners, the Chinese may not consider change as natural and may not believe that laws need to change when society changes. ${ }^{57}$ Indeed, the Chinese's lack of interest in change is supported by stories of the early Westerners who first "discovered" China. "From the beginning the Westerners... were highly interested in China and its ways.... [But i]t hardly occurred to the Chinese ruling classes that ... the Europeans might have anything to say that would be of great interest . ..."58

Again, Professor Head helps the reader through the heavy material with his casual style. For example, he explains that "we should pause here to get oriented"59 and acknowledges that he understands that some Chinese philosophy may "sound[] like hocus-pocus" to a "modern

52. Id. at 462-63 (emphasis omitted) (quoting BRADLEY SMITH \& WAN-Go WENG, CHINA-A HISTORY IN ART 12-13 (1973)) (internal quotation marks omitted).

53. See, e.g., id. at 465-66.

54. Id. at 468.

55. Id. at 470 .

56. Id. at 493 .

57. Id.

58. Id. at 498 (quoting HarRy G. Gelber, The Dragon AND the ForeIGn Devils: ChinA AND THE WORLD, 1100 BC TO THE PRESENT 36, 149 (2007)) (internal quotation marks omitted).

59. Id. at 473 . 
Westerner." 60 He cautions against "examin[ing] China through a telescope and seeing only [our] own reflection." 11 He peppers the pages with explanations of Chinese words and symbols ${ }^{62}$ and charts of dynasties. ${ }^{63}$ Interesting trivia emerges: in 124 BCE, China was the first to establish a civil service examination system. ${ }^{64}$

Perhaps the most important change in modern Chinese law was brought about by Communism. The Communist government believed that law was not intended to be "impartial" but was "a tool for the maintenance of state domination." 65 The Cultural Revolution "ground the administration of justice to a halt." ${ }^{26}$ After the death of Mao, the country sought to return to "laws that would be stable, applicable to all in society, and not subject to 'the whim of a particular leader." "67 The emphasis on stability was a return to traditional Chinese ideals of old. But new economic policies caused "[a] [l]egislative and [r]egulatory [f]renzy" that has continued today. ${ }^{68}$ Throughout these changes, China struggled to keep its own traditions, although modern Chinese scholars, at any rate, have shown extensive interest in foreign legal systems. ${ }^{69}$ Professor Head argues that this dichotomy led to a "mixed set of reforms" in which some of China's new laws bear a resemblance to Western laws, while others, such as family law, bear no similarity at all. $^{70}$ He concludes that "the challenge of aggressive, overreaching Western powers has planted in many Chinese a bitterness and suspicion against all things Western... that seem to demand and celebrate individual self-sufficiency at the expense of family and community.",71

In Chapter 7, the last “operational” chapter, Professor Head explores contemporary Chinese law, ${ }^{72}$ particularly criminal procedure, by

60. Id. at 475 .

61. Id. at 485 .

62. Id. at $465-66$.

63. See, e.g., id. at 460-62.

64. Id. at 475 .

65. Id. at 518 (quoting BIN LiANG, THE CHANGING CHINESE LEGAL SYSTEM, 1978-PRESENT 19 (2008)) (internal quotations marks omitted).

66. Id. at 520 (quoting Volker Behr, Development of a New Legal System in the People's Republic of China, 67 LA. L. REV. 1161, 1163 (2007)) (internal quotation marks omitted).

67. Id. at 521.

68. Id. at 521-22.

69. Id. at $525-26$.

70. Id. at 533 (emphasis omitted).

71. Id. at 535 .

72. Id. at 539-645. 
comparing its aspects as they appear "on paper" and "in practice.,"73 On paper, Chinese criminal procedure is not all that different from that of the civil law system. Trials are public; ${ }^{74}$ lay assessors participate along with judges at the trial; ${ }^{75}$ the investigation and procedure for interrogation seem to follow the inquisitorial model $;^{76}$ the victim is allowed to participate in the trial, ${ }^{77}$ the defendant has a right to an attorney, but he has no right to remain silent. ${ }^{78}$ The main difference from the civil law model seems to be that the defendant is not entitled to an attorney during the investigation stage. ${ }^{79}$

Most laws, however, are "local laws.",0 In non-criminal proceedings, administrative power is the rule that increasingly matters to individuals in society. ${ }^{81}$ The administrative power "covers and manages everything from cradle to grave." ${ }^{82}$ Judges are not truly independent, and decisions of judges are not precedential. ${ }^{83}$ "Special personal relationship[s]"-in other words, who knows whom-continue to serve as an "extra legal mechanism" for handling affairs in China. ${ }^{84}$ Still, China is experiencing rapid change that makes it difficult to ascertain the "soul" of its legal system. ${ }^{85}$ At this point only time will tell.

\section{GENERAl COMMENTS ABOUT STYLE AND READABILITY}

One should study together the history of a legal system and that system's present-day operation. At least that is Professor Head's premise and method. ${ }^{86}$ He is wise enough, though, to know that some

3. Id. at $590-605$.

74. Id. at 596 .

75. Id.

76. Id. at 594 .

77. Id. at 599 .

78. Id. at 598 .

79. Id. at 594 .

80. Id. at 577 (quoting WENXIAN ZHANG, JURISPRUDENCE 133-36 (2007)) (internal quotation marks omitted).

81. Id. at 564 .

82. Id. (quoting Wang Zhoujun, Democracy, Rule of Law and Human Rights Protection Under Gradually Developed Constitutionalism-By the Clue of Administrative Law, 2 FroNTIERS L. CHINA 335, 339 (2007)) (internal quotation marks omitted).

83. Id. at $584-88$.

84. Id. at 572 (quoting PitTMAn B. PotTer, The Chinese Legal System: Globalization AND LOCAL LEGAL CULTURE 12 (2001)) (internal quotation marks omitted).

85. Id. at 644 .

86. See supra notes $4-6$ and accompanying text. 
readers will be interested in only one of the two. His organization makes it easy for a reader to choose which of the three systems to focus on and enables a quick look or an in-depth study of either. For instance, one who wants to know only the procedural aspects of modern civil law systems could skip straight to Chapter Three. The choice is the reader's.

Each chapter begins with Study Questions. ${ }^{87}$ These give the reader a preview of the issues to be discussed as well as a useful method of review. Students should find these particularly useful. The Bibliography helpfully lists its sources by topic. ${ }^{88}$

This book includes many user-friendly resources. These comprise charts, ${ }^{89}$ diagrams, ${ }^{90}$ and maps, ${ }^{91}$ along with biographical sketches of the likes of Machiavelli, ${ }^{92}$ Napoleon Bonaparte, ${ }^{93}$ and King John. ${ }^{94}$ Professor Head includes photographs ${ }^{95}$ and lists, such as "English Sovereigns Beginning with William I." 96 Boxes contain helpful facts, such as "Key Developments in the History of Ancient Rome." detailed comparative timeline near the start of the book places the important dates of all three systems in sharp comparison in side-by-side columns. $^{98}$ Flow charts show the process of a criminal case through various court systems. ${ }^{99}$ Professor Head has even penned catchy tunes to help remember dates, such as "History of the Chinese Legal Tradition in Song." 100 These visual aids, along with the informative appendices, bring the materials to life. Professor Head uses a casual but lively voice, feeling free to utilize slang and non-legal terms to enlighten the reader. His own extensive travel and work in foreign countries allow him to make "personal observations"101 that give his statements an authenticity that is lacking in the typical tome. All of these devices make otherwise

\footnotetext{
87. See, e.g., HEAD, supra note 1 , at 4.

88. Id. at 655-59.

89. See, e.g., id. at 491.

90. See, e.g., id. at 145.

91. See, e.g., id. at 47.

92. Id. at 129-30.

93. Id. at 133-35.

94. Id. at 393-94.

95. See, e.g., id. at 596.

96. Id. at 392.

97. Id. at 49 .

98. Id. at 32-37.

99. See, e.g., id. at 324.

100. Id. at 536 .

101. Id. at xix-xxi, 661 .
} 
dense material entertaining and accessible.

One criticism I have is that the timeline at the start of the book was assembled out of order. ${ }^{102}$ This was the fault of the publisher and will likely be repaired in future editions. My only other criticism is of the Index. ${ }^{103}$ It lacks the specificity that I desire in an index. While trying to relocate things I had read in the text so that I could quote them in this review, I examined the Index only to find it lacked the extensiveness I expected to find. Further, there was no reference to my colleague, Myron Moskovitz, whose article was reprinted in its entirety at the end of Chapter Three. ${ }^{104}$ I am sure there are other omissions in the Index as well. If these are the only parts of the book that I can find fault with, however, I must conclude that the book is nearly perfect.

\section{CONCLUSION}

John Head has written an incredibly detailed and impressive history of three important legal systems: civil law, common law, and Chinese law. Each of these systems has a rich tradition that he deftly compressed and explained in simple terms in the book. In addition to the history, Professor Head has explained the "nuts and bolts" of the present-day operation of these systems. This knowledge is important to an understanding of law in an increasingly global world. I highly recommend Great Legal Traditions to historians, sociologists, political scientists, lawyers, law students, and anyone who is interested in the evolution of law throughout the ages or in the present workings of the three major legal systems.

102. Id. at $32-37$.

103. See id. at 663-76.

104. Id. at 255-301. 